\title{
Internship in School Psychology: Education and practice of the supervisor
}

\author{
Estágio em Psicologia Escolar: formação \\ e prática do supervisor
}

\author{
Walter Mariano de Faria SILVA NETO' \\ Raquel Souza Lobo GUZZO²
}

\begin{abstract}
The aim of the study was to investigate the training and practice of the internship supervisor in the field of Educational Psychology. The research was carried out through semi-structured interviews with six internship supervisors. Data was collected into three groups, as follows: characteristics of the supervisor (emphasis on the importance of his/her personal and professional background); relationship with the working setting (knowledge on curriculum structure and on the relationship between field activities and supervision); and training possibilities for the psychologist (emphasis on the potential of the field to understand the reality and intervention). The results suggest that the supervisor profile, national educational legislation, policies for the expansion of undergraduate courses, night undergraduate courses, and the workload are specific conditions required to become a supervisor. Thus, the integration of training-practice is important for the professional supervisor.
\end{abstract}

Keywords: Critical psychology; Internship supervision; Professional education; School psychology.

\section{Resumo}

Este trabalho objetivou investigar a formação e a prática do supervisor de estágio em Psicologia Escolar. A pesquisa foi desenvolvida mediante entrevistas semiestruturadas com seis supervisores da Região Metropolitana de Campinas, SP. Os dados foram agrupados em quatro conjuntos: características do supervisor (ênfase na trajetória pessoal e profissional); relação com o contexto de trabalho (referente ao conhecimento da estrutura curricular e à relação com a organização das atividades de campo e supervisão); possibilidades para formação do psicólogo (destaque ao potencial da área para compreender a realidade e a intervenção necessária, além de referenciais teóricos [diversidade de autores utilizados]). Os resultados sugerem que, além do perfil do supervisor, a legislação educacional nacional, as políticas de expansão dos cursos universitários, as práticas de cursos noturnos e a carga horária de trabalho são condições para o exercício da supervisão. Daí a importância da integração formação-prática na constituição do papel profissional do supervisor.

Palavras-chave: Psicologia crítica; Supervisão de estágio; Formação profissional; Psicologia escolar.

\footnotetext{
$\nabla \nabla v$

${ }^{1}$ Universidade de Uberaba, Pró-Reitoria de Ensino Superior, Curso de Psicologia. Uberaba, MG, Brasil.

2 Pontifícia Universidade Católica de Campinas, Centro de Ciências da Vida, Programa de Pós-Graduação em Psicologia. Av. John Boyd Dunlop, s/n., Jardim Ipaussurama, 13060-904, Campinas, SP, Brasil. Correspondência para/Correspondence to: R.S.L. GUZZO. E-mail: $<$ rguzzo@mpc.com.br>.

Article based on Doctoral dissertation of W.M.F. SILVA NETO, intitled: "Supervisão de Estágio em Psicologia Escolar: contribuições da Psicologia Crítica à formação e prática do supervisor”. Pontifícia Universidade Católica de Campinas, 2014.

Support: Coordenação de Aperfeiçoamento de Pessoal de Nível Superior.
} 
The formation of Brazilian psychologists began in the 1950s, before the profession was regulated in August 27, 1962; in 1963, a minimum curriculum was required as mandatory professional training for practical activity (Soares, 2010).

Since 1990, with the increase of undergraduate Psychology programs, the minimum curriculum proved insufficient to meet the demands of the profession. The Diretrizes Curriculares Nacionais (DCN, National Curriculum Guidelines) (Conselho Nacional Educação, 2004) were established in an endeavor to meet the demands of training and professional work reality - particularly professional practice in public services, and not just in private services. According to the DCN, Psychology programs should give an emphasis on the furthering of studies according to the different fields of work of psychologists. However, professionals and institutions related to Psychology as a field of academic and professional training discussed the emphasis given to basic training; difficulties related to the understanding of the role of curriculum emphasis regarding the structure of Psychology programs and how they were related to supervised internships in specific fields of professional practice prevailed (Tizzei, 2014).

Professional training has been neglected from policies of profile assessment and professional preparation of those who graduate to practice Psychology in various fields. In 2013, the Conselho Federal de Psicologia (CFP, Federal Council of Psychology) published an article offering contributions to the discussion on the training of the psychologist. The article was the result of a workshop whose purpose was to address significant issues useful to guide the future process of training professionals who pursue a Psychology career. Moreover, Psychology should be committed to everyday social issues that challenge science and professional practice. One of the points of the discussion related to training focused on the importance of the academic curriculum and the ethical-political project. The discussion highlighted the gap between what is stated in the curriculum and what occurs in fact during professional training. Another important point of the discussion was adopted by the psychologists who educate the students: the guidelines for the professional profile are not clear and they ignore the DCN. The professional profile is not theoretically forged, but rather developed through practical activities in the real world and based on clear and coherent philosophical and theoretical foundations. Thus, this is an obstacle for critical training because training is not based on an understanding of the situation and on the assessment of the consequences of professional activity (Caniato, 2013).

The focus of the article is the relationship between Psychology and Education, discussing supervised internship in Educational Psychology. Our purpose is to discuss the performance of internship supervisors in the light of a critique of their practice. We argue that the activity of supervisors in the field and their critical understanding of the educational reality are key elements to prepare professionals committed to the field who are challenged to improve it. To support the critical understanding of the data, as well as the findings of the study, some of the central topics were briefly discussed; the main facts regarding the institutionalization process of Psychology and the professionals served as an argumentative structure to defend the thesis.

\section{Institutionalization of Psychology as a professional-academic field}

The year of 1975 was considered the period of professionalization of Psychology (Pereira \& Pereira Neto, 2003) because it was when the profession became organized and recognized, though - it is worth emphasizing -, subject to socioeconomic changes. According to these authors, subjection demeaned labor to a point that psychologists had to venture in different fields and compete with professionals from other areas.

The movement for professional expansion required the definition of the professional psychologist; and this requirement was fulfilled with the minimum curriculum for Psychology programs established by the Conselho Federal de Educação through the Resolution n 403/62 (Conselho Federal de Educação, 1962), which became effective as of 
1963 (Mello, 1989). The resolution also established the need for practical activity in the form of supervised training.

Since 1990, the number of Psychology programs increased, in part due to the increase of private colleges (Silva Neto, Tizzei, \& Guzzo, 2012; Tizzei, Silva Neto, \& Guzzo, 2013) in agreement with the neoliberal agenda of the federal government. In this context, the change in education occurred after the publication of the DCN for the Psychology programs that characterized general training, in which three large areas comprise the minimum curriculum (School and Educational Psychology, Clinical Psychology and Applied Psychology to Work), according to the Law $n^{\circ} 4119$ / 62 (Brasil, 1962). It was determined that the programs had to have at least two curricular emphases present in the educational program according to the characteristics of the region where the programs were located.

Thus, after Psychology was listed as a profession in Brazil, many developments have led to its institutionalization, particularly as a liberal profession serving a social group who can afford the service. Only after professionals entered public service - at first through health care, then social assistance -, was when training issues became an important field of research, particularly due to contradictions regarding the guidelines determined by the DCN.

\section{Emphasis on training}

The guidelines were widely discussed in Psychology associations: the consequence of the curriculum emphasis on basic training of psychologists affected the relationship of some fields of Psychology that could not be covered in undergraduate courses (Buettner, 2000). According to Buettner, although the emphases are still present during training, the theoretical-methodological and professional diversity must be assured; that is, the pluralist character and general training needs to be privileged.

Cruces (2009) states that most degrees in Psychology focus on health and clinical processes, which corroborates the historical trend in the field. The author argues that of 60 institutions that have published information about the emphases adopted on their websites, 22 institutions focus on educational processes. The researcher understood this discrepancy as an indication of the importance of the field of study.

After the professionalization of the psychologist, some questions stand out: the social context, teacher training and ways of conceiving the development processes of students is often tied to European theoretical concepts from the XIX and $X X$ centuries and the learning processes are connected to a strong pragmatic American tradition and interactionist references. This multifaceted character often gives the future psychologist a view that does not go beyond the field under criticism, without being able to see ways to change reality.

The focus of training - and practice -, of Psychology and education professionals is grounded on what Patto (1990) calls the extracurricular causes of school failure; in other words, school failure of children is related to personal difficulties or to their families. According to the author, combined with public policies and the functioning of the school itself - given its historical determinants that directly affect the quality of education -, the intracurricular causes are not an important part of the analysis concerning failure. The excessive number of students in the classes, low wages, poor material conditions of school's facilities due to lack of resources for maintenance, among other elements, are essential to analyze school failure (Patto, 1990). According to Machado and Souza (1997), the procedures teachers adopt when a child "allegedly does not learn" are equally significant; guilt appears in Psychology services in primary healthcare as psychologists frequently treat a complaint clinically.

When challenging the prevailing view in Psychology, Guzzo (2007) addresses the need for Psychology to be able to oppose the dominant ideas in professional practice. Because Psychology theories are detached from reality, they do not understand the real conditions for human development; to make understanding possible, requires exceeding the limits within which the Psychology professional 
does not belong to the educational network; that is, training in the field must overcome an essential element: the reality of practice. One way to overcome the problem is to participate in education and help develop policies that intervene in how concepts of human development and school are developed. It is within this perspective and based on the experience of a group of supervisors that we discuss supervision in School Psychology and how it differs from internship supervision in School Psychology (Silva Neto, 2014).

\section{Supervision during Psychology training}

The scientific investigation about internship during training has productions that present and/or report experiences of trainees and issues related to practice (Delvan, Ramos, \& Dias, 2002; Emilio, Mataresi, Horvat, \& Figueiredo, 2012; Ulup $\&$ Barbosa, 2012). The focus is the role of internship during education associated with the theoretical perspectives and strategies used in practice (Delvan et al., 2002). At the same time, the placement of the trainee in practical scenarios, in particular at school, is perceived as a maturing landmark for the psychologists in training, as it helps them develop skills and understand the professional activity (Ulup \& Barbosa, 2012). Emilio et al. (2012), when addressing the training of a group of trainees in School Psychology, focused on the experience of the supervisor. They discussed how the trainees caused the supervisors to respond in a way that, the supervisor, had to be aware of the trainees' feelings and anxieties during internship practice to learn how to identify them.

Distance during supervision can provide moments for reflection about practice, but without being able to reconstruct it. As for the school, institutional phenomena can be understood and, in future situations, students may hold instrumentality perceptions acting in accordance with a critical concept. The supervisor needs to perceive these aspects during supervision, as it is during supervision that trainee can overcome the superficial idea of reality that enables further critical understanding: going beyond professional practice techniques.
This type of focused approach on experience reports of internships is common in Psychology or Education. In a theoretical reflection on the subject, Cosmo (2011) presented aspects of the complexity of psychological practices in the school context and their objectives related to health promotion in the school community. Didactically, the author summarizes the stages required to structure and perform internships for these purposes: qualification; choosing the practice setting; conducting institutional research; preparing the intervention proposed, and finalizing and evaluating internship. Another objective of internship should be professional training for critical-reflexive action, converging to current ideas.

Angst and Silva (2009), in turn, report their experience in a school advisory service that is characterized as a collaborative process among professionals, teachers, principals and students to identify needs and select strategies useful to solve collective problems. The article discusses aspects of the activities of the internship supervisor; the supervisor, in order to contribute to the practices developed by the trainee, assists and prepares them to reflect on issues and search for answers appropriate to the reality where they work as a trainee, envisioning professional practice. One author was a trainee and the other a supervisor, and both concluded that the experience promotes trainees' growth and attitudes toward professional practice, not only regarding School Psychology, but also in other fields of the psychologist.

The study of Macarini, Martins, and Vieira (2009) describes the activities of the trainees at the institution that focuses on tasks related to daycare; internship is seen as a form of psychological intervention in the institution. Leal, Facci, Albuquerque, Tuleski, and Barroco (2005) analyze internship school reports with an emphasis on the description of activities: workshops, continuing education, outreach programs, orientation activities to schools, issues relevant to Psychology and Education, as well as a program for children with learning difficulties (with guidance from parents and teachers). Lima (2009) describes the importance of the relationship between theory and practice in establishing partnerships with elementary schools 
and criticizes clinical training of trainees who need to adapt to the school's different concept of professional activity. Ulup and Barbosa (2012) also refer to the importance of the relationship between theory and practice in carrying out activities at school, giving special emphasis to dialogue between Psychology and Education. In this sense, they question the importance of discussing the understanding of real life conditions present at school practices during internship as well as the issues related to the traditional position of professional psychologists in this field: issuers of medical reports and diagnoses.

Another article worth mentioning is the one by Asbahr, Martins, and Mazzolini (2011, p.169). These authors visited schools to describe the evolution of internship with children with learning problems, because trainees used to attend at service school. The researchers believe to have contributed to the development of intervention alternatives "... without classifying the child and family as being uninterested in the educational process or as having school pathology".

With regard to supervision as a process, the study of Silva (2004, p.89) on the art of supervision and how trainees build their career considers "... supervision to be a privileged moment of learning as it allows students to reflect on their activities, thoughts and feelings during their preparation for practice"; and the experience of the supervisor must be assumed when preparing internship proposals. In another article, Silva, Ribeiro, and Marçal (2004, p.87) state that the role of supervision is "... to promote reflection about the techniques used in Psychology, giving emphases on the preparation of the trainees' career".

Regarding experience during internship, Melo-Silva (1999a, 1999b), within the framework of vocational guidance, sees internship as a moment to develop professional identity.

\section{Internship supervision: An important element of the training of school psychologists}

In the state of São Paulo, Brazil, psychologists offered the first internship programs in School
Psychology from the State Department of Education (Taverna, 2003). But, as Gonçalves (2000) points out, there is no definition of the professional profile of the supervisors, nor any criteria for hiring them in Higher Education. According to the author,

\begin{abstract}
... . This didactic-pedagogical modality is a bridge between theoretical and scientific training, held inside the universities and the practical and technical realities of the environment, in order to promote objective student participation in professional situations in a specific area to establish correlations between these situations and theoretical framework (Gonçalves, 2000, p.14).
\end{abstract}

In the field of School Psychology, according to the author, there is a lack of studies on the description of the activities of the internship supervisor. Often, the references still follow clinical perspectives, which support the representation of the clinical practice of psychologists in the educational field. According to Guzzo, Costa, and Sant'Ana (2009), it is also important to consider the relationship between theory and practice established during internship to build a professional identity that relates to "being in the world" of professional training.

The role of the psychologist as an internship supervisor is not limited to technical issues. It is important to consider the social and political commitment during supervision. According to Brandão (1995), this is an important element of the supervisors' work. The author points out that professional experience and continuing education determine the quality of work performed by supervisors. In the social field, the author highlights the importance of understanding educational reality and establishes an association with macro-structural aspects, in addition to knowledge of government policies and their relation to the understanding of the political nature of the activities that the professional develops in the educational field, provided they are contextualized from an ideological point of view. According to Silva (2002, p.212), the psychologist can establish partnerships with schools 
during internships, allowing the student to have more contact with the educational reality and "... see in loco the feasibility of work in educational institutions".

\section{Method}

To conduct the study, a survey was performed in the database of the Ministry of Education, named e-Mec (Brasil, 2015) to identify universities in the metropolitan region of Campinas (SP) that offered Psychology programs. The coordinators of the courses of seven universities were contacted according to the requirement of the Research Ethics Committee, report n² 263.832/13. Only three of these courses offered internships in the field of School Psychology. After this, we contacted the internship supervisors and invited them to participate in the study. Among the supervisors contacted, six accepted to participate in the study and they were interviewed individually.

The interviews followed a script that focused on biography, training and professional practice, work environment, curriculum structure and the involvement in the field. Participants were interviewed according to their individual schedule and the audio recording material was transcribed and organized into global categories according to the method of content analysis proposed by Bardin (1977), which is described in the next section.

All supervisors performed internship in School Psychology while attending basic training and they all have a master's or doctoral degrees (one participant is doing doctoral studies) in Psychology or Education. The work experience of the participants ranges from 10 years to 31 years; but they have less teaching experience (between 4 years and 14 years). The supervisor experience ranged from 2 years to 15 years.

\section{Results and Discussion}

The statements of the respondents were organized into four categories.

\section{Supervisor characteristics}

This category included specific characterization of the supervisors in the study and provided details about their personal and professional career in the field of School Psychology and related areas. The specific characterization of the supervisors was one of the objects of analysis of the research because specific training is an important personal characteristic of the supervisor. In addition to those aspects, the professional experience of the supervisors such as their experience as psychologists, professors and supervisors were included. They outlined their professional experiences in private elementary schools and rehabilitation centers for children with learning difficulties; however, no participant had previous work experience in public schools. The respondents who did not have prior experience in public schools worked in different fields of Psychology, which was not related to their field of work as internship supervisors.

All jobs cited by the participants were in nongovernmental organizations as consultants for the municipal government. No supervisor had specific experience in the public education network, which implies that there are manifold possibilities for the psychologist who gets involved in education, even though they do not participate in public policies (Guzzo \& Mezzalira, 2011; Guzzo, Moreira, \& Mezzalira, 2013).

Respondents became supervisors based on their professional experience in different fields of education: middle schools, special education schools, departments of education, and later in higher education teaching and internship supervision. Only one respondent became a supervisor without any prior professional experience in the field. All respondents teach courses related to the specific field of School Psychology and related areas, such as Educational Psychology, at undergraduate teaching courses, and educational or School Psychology courses in undergraduate Psychology programs - adolescent development. They also teach courses that can potentially help the critical thinking of undergraduate students (Epistemology, Research Methods, Institutional Psychology, Public 
Policies, Historical and Critical Psychology, Integrated Psychology and Practical Psychology). One of the respondents, in addition to supervising internships, advises graduate students in the field of historical and cultural Psychology. Respondents stated that they became interested in other areas of Psychology. One of the respondents considers that the activities of the entities related to their field are not in agreement with what he/she believes, particularly regarding the role of the CFP in strengthening the field.

Indeed, according to Silva (2004), the closeness between students and supervisors is an important aspect that influences and affects the development of the professional activities of students. When the supervisor is involved in the training process and concerned with conceptual, methodological, behavioural and ethical issues, the endeavour to seek other models of professional performance becomes evident.

According to participants, supervisory activity involves a smaller number of students, which favours a different teaching approach in the classroom. Therefore, it allows a more intense relationship that contributes not only to the professional development of the future psychologists, but also to their personal growth. Furthermore, this can also contribute to the development of the supervisor.

\section{Relationship with the work context}

This category involved the supervisors' descriptions of how they see the university concerning their relationship with the work activity connected to the description of the supervisory practices. The work context was a relevant characteristic because, with the exception of one professor who supervises internships at nongovernmental organizations, the professors supervise internships in public institutions. They argue that one cannot distinguish the institutions from social reality. It is worth stating that the working conditions of the supervisors directly interfere with internship activity because most of them cannot supervise the activities developed by the trainees closely as they are not paid for the extra hours of work.

Of the bureaucratic aspects involving the main characteristic of internships - such as workload of internships and internship programs -, the number of students per supervision group is what mostly interferes with training. According to DCN, trainee groups should range from 8 to 14 people; while in undergraduate courses there are approximately 60 students per class. The working arrangements of all the supervisors are per semester and they teach day and night classes. The others teach night courses. This is a challenge because a number of situations must be taken into account, particularly for internship supervisors. One example is the compatibility of the work schedule with the timetable of the institution where the internships occur. The workload of a supervisor ranges from three to four hours a week, which includes the discussion of activities and theoretical discussions that help students prepare their final reports, when necessary.

Regarding knowledge about the program established by the university, one participant stated being involved in development of the pedagogical project for the Psychology program where he/she worked as a supervisor. The other respondents did not show clear understanding of the emphases and reported the differences between the presence of school psychologists in basic and professional internships. Knowing the emphasis and the pedagogical project of the program allows the supervisors to align their practices to the expectations outlined by the institution during the training of the psychologist in accordance with the graduate profile. At the same time, this requires reconsidering these instruments for a more critical approach and being committed to social reality. The lack of these characteristics, it should be said, interferes with the work of the supervisors: how the supervisors associate their activities with other areas of the course and how the supervisors interact with their colleagues and the institution leads to the reproduction and maintenance of the status quo. 
In this study, the pedagogical project was not considered an important aspect during the training of students. These data confirm the thesis that if supervisors are committed to the curricular emphases and the profile established by the pedagogical project, supervision becomes simply technical, satisfying the market demands; but, in the case of the education, most Psychology students are not interested in technical/pedagogical knowledge.

An important question concerns the relationship between students and internship programs. Most students enrol in internship programs because they are a mandatory requirement. A supervisor reported, "... it is common to hear a student say, 'I am not interested in education'". In undergraduate Psychology programs, students generally have to fulfil internships in at least two areas of studies or emphasis. Some programs prioritize different areas, but on average the student has to fulfil at least 500 hours of compulsory training in more than one area. This is because the training of psychologists, according to the DCN, is still general. After graduation, psychologists can work in any field of Psychology, even though they are often not well prepared for all of them. However, some graduates discover the possibilities of education due to the impact of internship supervision.

Internship is considered a privileged place for supervisors and students during training. There is direct contact during supervision and elements that allow the questioning of other experiences and reflections. In most universities, trainees can choose the field of intervention or internship from a list of options. This seems to be an advantage as they may previously know the contexts in which they will develop their activities. Supervisors also reported that trainees begin their work with issues that are discussed during supervision, frequently issues that discuss their expectations concerning performance and employment.

Regarding the importance of previous contact with trainees, the supervisor-student relationship plays an essential role not only for activity of students (Silva, 2004). This notion implies that students' experience with the supervisor provides much more than learning techniques - it develops a sense of meaning that will help the student/professional decide a career trajectory. This issue particularly involves the role of the supervisors as facilitators, who should always be aware of how they interrelate with trainees and serve as a professional "model". In other words, it is extremely important that supervisors understand that the experience of learning is more than content itself because it affects the perception of the world, the theoretical and methodological contributions, the ethical conduct and commitment, among other aspects.

\section{Training opportunities}

This category collected data found during research concerning the role of the supervisor as a key element that helps the trainee become a professional and critically reflect on the real demands of School Psychology. Internships characteristically approach a problem situation identified in the area (students with learning disabilities or referral to other services, for example) associated with traditional activities, which are expanded as the emergence of criticality is identified in the activity of supervisors. In addition, the definition of the activities, as well as the theoretical references, alludes to internship, which shows a commitment of the respondents to praxis.

The supervisory characteristics adopt an institutional discourse, as found in the statements of the respondents. Although we perceived an appreciation of relationships and how they are shaped during the process, it is clear that the design of supervision follows the rationale of the university.

\section{Theoretical framework}

As for the theoretical framework used by the supervisors, one of them states not having any and that it is a "... much more complicated situation". As for the others, they use several references directly related to their fields of study, 
which can be divided into three groups: 1) theoretical contributions related to critical theory with reference to Adorno and Horkheimer; 2) authors who regard themselves belonging to the theory perspective of Critical School Psychology, with national authors such as Marisa Meira, Maria Helena Souza Patto, Raquel Souza Lobo Guzzo, Adriana Marcondes, Marilene Proença Rebelo de Souza, Silvia Koller, and Carla Biancha Angelucci; 3) contributions from Educational Psychology that include the authors Alicia Fernandes and Cleo Fanti. Some supervisors use authors related to their academic studies, such as Urie Bronfenbrenner.

The foundation of theoretical framework offers, of course, further understanding of the supervisor activity and internship practice. As stated by the supervisors, School Psychology and its practices are based on concepts that are connected to the historical reproduction of hegemonic models and when other references are used, particularly the most critical ones, one can contextualize and associate professional practice to social reality (Cruces, 2003; Yazlle, 1990). However, it should be mentioned that School Psychology is a daily construction because critical references, in recent years, have become more frequent regarding interventional practices in this field.

\section{Final Considerations}

In reference to these distinct positions in the categories analysed, it may be concluded that higher education has these characteristics and that some issues, such as the focus on the transformation of professional practice and the everyday reality of the population, are ignored when meeting the logic of the market. This briefly summarizes Psychology training.

Perhaps this is why Dias (1998) states that internship supervision should focus on the training of psychologists, making them able to question practice itself within a contextual dimension; but she warns -, this is only possible when practice is effective during training. The author states that supervision is not an end in itself - to obtain a diploma; it must be an important moment for the development of maturity on the issues studied during the course that are not easily understood in everyday training. Higher education should prepare the professional for practice, as well as life in society, and the supervisors themselves must achieve this goal.

The characteristics of supervision discussed in the present study tend to meet institutional protocols, but internship experience must be focused on other models other than those focused on the unhealthiest of life. In general, the best internship experiences have been achieved in programs that promote the interaction of different areas and fields, while contextualizing and relating to the real life experiences of children, adolescents, schools, families and communities (Lima, 2009).

With regard to the potential of internships during the training of the psychologist, whenever discussing internships, the subjective dimensions involved in this process are considered, particularly in the case of supervised internships, which is an essential element of training. Internship allows the students to consider and evaluate the progress of experience, as well as to plan, intervene and evaluate the results and performance at schools, health institutions or other types of healthcare scenarios (Mattos, Nuernberg, \& Carneiro, 2009).

When analyzing experiences of supervised internships in schools, Nunes, Silva, and Lima (2009) believe that the training of the school psychologist is essential to promote significant and quality practice, contributing to the transformation of subjectivity and society. Therefore, care is essential during the training process and the future psychologist must have experiences, before graduation, that foster the development of a critical view and an emancipatory political conception of the socio-historical roots of the educational process, among other issues. One issue discussed by the supervisors interviewed was that internship is not a practice within itself, but an activity that promotes professional experience during training. According to Lima (2009), supervised training is the link between theory and practice, serving as an instrument that increases knowledge and stimulates 
the discussion of techniques, behaviours and practices that may be adopted by the professional.

This study confirmed that the training of psychologists consists of neuralgic issues. One of them refers to the work in education. Internships converge to face the challenges of training, as they can strengthen the development of other practices other than the hegemonic practices. However, these practices cannot be decontextualized from social and cultural reality; rather, they need to associate theoretical constructs with practice and knowledge in a critical and reflexive manner.

It is clear that the local understanding of internship is a precondition for the concept of supervision, as it can break conservative thinking (Assis \& Rosado, 2012). In the case of School Psychology, it must contribute to the development of new professional skills, not only during the training process, but consider the placement of students in the labor market more critically. It is understood that supervisory internship in School Psychology has a privileged place because it means and allows the assignment of meaning to the professional practices of students and how practices will be managed over time by breaking traditional, guilty and individualized practices. This will be possible when continuous and contextualized training is associated with the national realities.

This issue also highlights the tension between conservative practices that may emerge from the context of training and professional projects defended and associated with a particular political area. In short, according to Frigotto (1995), supervision in School Psychology can be a training element capable of expanding the democratic experiences of resistance.

\section{Contributors}

All authors contributed to the conception and design of the study, data analysis and final editing.

\section{References}

Angst, R., \& Silva, M. B. (2009). Consultoria escolar: uma experiência de estágio. Anais do IX Congresso Nacional de Educação e III Encontro Sul-brasileiro de Psicopedagogia (Vol.1), Curitiba.

Asbahr, F. S. F., Martins, E., \& Mazzolini, B. P. M. (2011). Psicologia, formação de psicólogos e a escola: desafios contemporâneos. Psicologia em Estudo, 16(1), 157-163.

Assis, R. L. M., \& Rosado, I. V. M. (2012). A unidade teoria-prática e o papel da supervisão de estágio nessa construção. Revista Katálysis, 15(2), 203-211.

Bardin, L. (1977). Análise de conteúdo. Lisboa: Edições 70.

Brandão, S. C. (1995). Aspectos sociais e políticos na formação em Psicologia Escolar: opinião de supervisores (Dissertação de mestrado não-publicada). Pontifícia Universidade Católica de Campinas.

Brasil. Presidência da República. (1962). Lei nº 4.119, de 27 de agosto de 1962. Dispõe sobre os cursos de formação em Psicologia e regulamenta a profissão de psicólogo. Diário Oficial da União, 1962, Seção 1, p.9253.

Brasil. Ministério da Educação. (2015). E-Mec. Recuperado em março 18, 2015, de http://emec.mec.gov.br/

Buettner, G. E. B. P. (2000). Diretrizes curriculares em Psicologia: discursos de resistência (Tese de doutorado não-publicada). Pontifícia Universidade Católica de Campinas.

Caniato, A. (2013). A formação de psicólogas e psicólogos: respondendo às demandas da sociedade brasileira. In Conselho Federal de Psicologia. Documento do CFP sobre a formação de psicólogas e psicólogos. Brasília: Autor.

Conselho Federal de Educação. (1962). Parecer $n^{\circ} 403 /$ 62 do CFE, aprovado em 19/12/62. Recuperado em março 18, 2015, de http://www.abepsi.org.br/portal/ wp-content/uploads/2011/07/1962-parecern403 de19621.pdf

Conselho Nacional de Educação. (2004). Resolução CNE/ CES no 8, de 7 de maio de 2004. Institui Diretrizes Curriculares Nacionais do curso de graduação em Psicologia. Diário Oficial da União, 2004, Seção 1, p.16-17.

Cosmo, N. C. (2011). Práticas psicológicas em contextos educativos: alguns apontamentos relativos ao estágio curricular específico. Anais do X Congresso Nacional de Psicologia Escolar e Educacional (Vol.1), Maringá.

Cruces, A. V. V. (2003). Psicologia e educação: nossa história e nossa realidade. In S. F. C. Almeida (Org.), Psicologia Escolar: ética e competências na formação e atuação profissional (pp.17-36). Campinas: Alínea.

Cruces, A. V. V. (2009). Desafios e perspectivas para a Psicologia Escolar com a implantação das diretrizes curriculares. In C. M. Marinho-Araújo (Org.), Psicologia Escolar: novos cenários e contextos de pesquisa, formação e prática (pp.15-34). Campinas: Alínea.

Delvan, J. S., Ramos, M. C., \& Dias, M. B. (2002). A Psicologia Escolar/Educacional na educação infantil: 
o relato de uma experiência com pais e educadoras. Psicologia: Teoria e Prática, 4(1), 49-60.

Dias, R. M. S. (1998). Dos encontros em supervisão: devenires na formação de psicólogos. Temas em Psicologia, 6(1), 21-29.

Emílio, S. A., Mataresi, A., Horvat, C., \& Figueiredo, P. (2012). Reflexões sobre a experiência de um grupo de estágio em Psicologia Escolar. In R. Molina \& C. B. Angelucci (Orgs.), Interfaces entre Psicologia e Educação. Desafios para a formação do psicólogo (pp.125-33). São Paulo: Casa do Psicólogo.

Frigotto, G. (1995). Educação e a crise do capitalismo real. São Paulo: Cortez.

Gonçalves, C. L. C. (2000). Supervisão de estágio em Psicologia Escolar: perspectiva e atuação de supervisores (Tese de doutorado não-publicada). Pontifícia Universidade Católica de Campinas.

Guzzo, R. S. L. (2007). Psicologia e educação: que compromisso? Que relação? In A. V. B. Bastos \& N. M. D. Rocha (Orgs.), Psicologia: novas direções no diálogo com outros campos de saber (pp.357-378). São Paulo: Casa do Psicólogo.

Guzzo, R. S. L., Costa, A. S., \& Sant'Ana, I. M. (2009). Formando psicólogos escolares: problemas, vulnerabilidades, desafios e horizontes. In C. M. Marinho-Araújo (Org.), Psicologia Escolar: novos cenários e contextos de pesquisa, formação e prática (pp.35-52). Campinas: Alínea.

Guzzo, R. S. L., \& Mezzalira, A. S. C. (2011). 2008 - ano da educação para os psicólogos: encaminhamentos e próximos passos. In R. S. L. Guzzo \& C. M. Marinho-Araújo (Orgs.), Psicologia Escolar: identificando e superando barreiras (pp.11-31). Campinas: Alínea.

Guzzo, R. S. L., Moreira, A. P. G., \& Mezzalira, A. S. C. (2013). Intervenção psicossocial: teoria e prática na inserção do psicólogo em instituições públicas de ensino. In M. H. Bernardo, R. S. L. Guzzo, \& V. L. Souza (Orgs.), Psicologia social: perspectivas críticas de atuação e pesquisa (pp.69-89). Campinas: Alínea.

Leal, L. D., Facci, M. G. D., Albuquerque, R. A., Tuleski, S. C., \& Barroco, S. M. S. (2005). A clínica-escola e o estágio em Psicologia na área educacional: fundamentos teóricos e prática profissional. Psicologia da Educação, 21, 79-102.

Lima, M. F. E. M. (2009). Estágio supervisionado em Psicologia Escolar: desmistificando o modelo clínico. Psicologia: Ciência e Profissão, 29(3), 638-647.

Macarini, S. M., Martins, G. F., \& Vieira, M. L. (2009). Promovendo saúde e desenvolvimento na educação infantil: uma atuação da Psicologia. Paideia, 19(43), 231-237.

Machado, A. M., \& Souza, M. P. R. (Orgs.). (1997). Psicologia Escolar: em busca de novos rumos. São Paulo: Casa do Psicólogo.
Mattos, L. K., Nuernberg, A. H., \& Carneiro, M. S. (2009). O trabalho de estágio curricular não-obrigatório na área de Psicologia Escolar/Educacional em contextos de inclusão escolar da Universidade Federal de Santa Catarina. Anais IX Congresso Nacional de Psicologia Escolar e Educacional (Vol.1), São Paulo.

Mello, S. L. (1989). Currículo: quais mudanças ocorreram desde 1962? Psicologia: Ciência e Profissão, 9(1), 16-18.

Melo-Silva, L. L. (1999a). Estágio profissionalizante em orientação profissional: experiência de supervisão em um curso de Psicologia (I). Revista da ABOP, 3(1), 119-135.

Melo-Silva, L. L. (1999b). Estágio profissionalizante em orientação profissional: a visão de alguns psicólogos estagiários (II). Revista da ABOP, 3(1), 137-159.

Nunes, L. G. A., Silva, S. M. C., \& Lima, L. R. (2009). O estágio curricular como elemento indispensável na formação de psicólogos escolares. Anais IX Congresso Nacional de Psicologia Escolar e Educacional (Vol.1), São Paulo.

Patto, M. H. S. (1990). A produção do fracasso escolar: histórias de submissão e rebeldia. São Paulo: Casa do Psicólogo.

Pereira, F. M., \& Pereira Neto, A. (2003). O psicólogo no Brasil: notas sobre seu processo de profissionalização. Psicologia em Estudo, 8(2), 19-27.

Silva, S. M. C. (2002). Arte e educação: na confluência das áreas, a formação do psicólogo escolar (Tese de doutorado não-publicada). Universidade Estadual de Campinas.

Silva, S. M. C. (2004). Algumas reflexões sobre a arte e a formação do psicólogo. Psicologia: Ciência e Profissão, 24(4), 100-111.

Silva, S. M. C., Ribeiro, M. J., \& Marçal, V. P. B. (2004). Entrevistas em Psicologia Escolar: reflexões sobre o ensino e a prática. Psicologia Escolar e Educacional, 8(1), 85-90.

Silva Neto, W. M. F., Tizzei, R. P., \& Guzzo, R. S. L. (2012). Refletindo os indicadores sociais, políticos e econômicos presentes na abertura de cursos de Psicologia: a experiência da Região Metropolitana de Campinas. Anais do I Encontro Paulista da Associação Brasileira de Psicologia Escolar e Educacional (Vol. 1), São Paulo.

Silva Neto, W. M. F. (2014). Supervisão de estágio em Psicologia Escolar: contribuições da Psicologia Crítica à formação e prática do supervisor (Tese de doutorado não-publicada). Pontifícia Universidade Católica de Campinas.

Soares, A. R. (2010). A Psicologia no Brasil. Psicologia: Ciência e Profissão, 30(n.esp.), 8-41.

Taverna, C. S. R. (2003). Um estudo histórico sobre a Psicologia Escolar na Secretaria Municipal de Educação da Prefeitura de São Paulo (Tese de doutorado não-publicada). Pontifícia Universidade Católica de São Paulo. 
Tizzei, R. P., Silva Neto, W. M. F., \& Guzzo, R. S. L. (2013). Análise dos indicadores políticos, econômicos e sociais e a expansão dos cursos de Psicologia no estado de São Paulo. Livro de resumos XI Congresso Nacional de Psicologia Escolar e Educacional, Uberlândia.

Tizzei, R. P. (2014). Formação em Psicologia Escolar: perspectiva crítica na ênfase para o campo educativo (Tese de doutorado não-publicada). Pontifícia Universidade Católica de Campinas.

Ulup, L., \& Barbosa, R. B. (2012). A formação profissional e a ressignificação do papel do psicólogo no cenário escolar: uma proposta de atuação - de estagiários a psicólogos escolares. Psicologia: Ciência e Profissão, 32(1), 250-263.

Yazlle, E. G. (1990). A formação do psicólogo escolar no estado de São Paulo: subsídios para uma ação necessária (Tese de doutorado não-publicada). Pontifícia Universidade Católica de São Paulo.

Received: March 25, 2014

Final version: November 25, 2014

Approved: March 19, 2015 